\title{
KEBIJAKAN DAN PENGAMBILAN KEPUTUSAN DALAM LEMBAGA PENDIDIKAN ISLAM
}

\author{
Ahmad Sabri \\ Dosen Fakultas Tarbiyah IAIN Imam Bonjol Padang \\ e-mail: e-mail: ahmadsabri81@yahoo.co.id
}

\begin{abstract}
Human beings as individuals and social beings are constantly faced with various problems or issues that they encounter in almost every side of life. Precise decision making is required to overcome these problems so that all of the alternative solutions can be achieved optimally. One's position in an organization or institution has often been distracted by some polices and decision, and therefore, he or she has to consider solutions while keeping the organization runs well. This is so because in every organization whether big and small, the changing of situation such as personnel shift has often raised conflict and misunderstanding. These problems must be avoided or clarified. Policy and decision making in substantive Islamic education is not too much different from the common theories of policy and decision-making. However, the policy and decision-making in Islamic education is more focused on the principles outlined in the Quran and the Hadith of the Prophet (Peace be upon him).
\end{abstract}

Key words: policy, decision making, institution of Islamic education

\begin{abstract}
Abstrak: Manusia sebagai makhluk individu dan juga makhluk sosial senantiasa dihadapkan kepada berbagai persoalan atau masalah yang dijumpai hampir di setiap sisi kehidupannya. Semua bentuk persoalan atau masalah tersebut menuntut adanya pengambilan keputusan yang tepat dari sejumlah alternatif pemecahan agar semua yang direncanakan dapat tercapai secara optimal. Begitu pula halnya posisi dan kedudukan seseorang, baik dalam organisasi maupun lembaga, terkait dengan tugas-tugas dan tanggungjawab yang harus dilaksanakan, seringkali pula dihadapkan kepada kebijakan-kebijakan dan keputusan-keputusan yang harus diambil secara tepat agar roda organisasi beserta administrasinya dapat berjalan dengan baik dan lancar. Kebijakan dan pengambilan keputusan dalam lembaga pendidikan Islam secara substantif tidak terlalu jauh berbeda dengan teori-teori kebijakan dan pengambilan keputusan yang ada. Hanya saja kebijakan dan pengambilan keputusan dalam pendidikan Islam lebih mengacu kepada prinsip-prinsip yang telah digariskan dalam al-Quran dan hadis Nabi SAW.
\end{abstract}

Kata Kunci: kebijakan, pengambilan keputusan, lembaga pendidikan Islam

\section{PENDAHULUAN}

Kebijakan dan pengambilan keputusan adalah dua unsur yang saling berkaitan dan tidak bisa dipisahkan satu sama lain. Kebijakan adalah sesuatu yang lebih bersifat teoretis, sedangkan pengambilan keputusan lebih bersifat praktis. Tindakan pengambilan keputusan yang tidak didasarkan pada teoretis dapat mengurangi nilai keilmiahan sebuah keputusan, sedangkan kebijakan yang tidak disertai dengan pengambilan keputusan sulit akan menemukan wujudnya.

Pengambilan keputusan merupakan hal yang sangat urgen bagi setiap orang terutama bagi para pimpinan atau manajer. Eksistensi seorang pemimpin dalam kepemimpinannya dapat dilihat dari berbagai bentuk kebijakan dan keputusan yang diambilnya. Seorang pimpinan atau manajer yang efektif adalah pimpinan atau manajer yang mampu membuat kebijakan dan mengambil keputusan yang relevan. Nawawi (1993: 55-56) mengatakan bahwa organisasi hanya akan berfungsi jika para pemimpin memiliki kemampuan mengambil keputusan dan memerintahkan pelaksanaannya kepada anggota organisasi sesuai dengan bidang tugas dan tanggung jawabnya.

Selanjutnya tulisan ini berupaya menjadikan paradigma pendidikan Islam sebagai pisau analisis terhadap konsep tentang kebijakan dan pengambilan keputusan Islam sebagai agama universal yang ajarannya tidak saja terbatas pada hal-hal yang parsial, akan 
tetapi meliputi seluruh aspek kehidupan manusia.

\section{PENGERTIAN KEBIJAKAN DAN PENGAM- BILAN KEPUTUSAN}

\section{Pengertian Kebijakan}

Secara etimologi, istilah kebijakan berasal dari kata "bijak" yang berarti "selalu menggunakan akal budidaya; pandai; mahir" (Departemen Pendidikan Nasional, 2002: 149). Selanjutnya dengan memberi imbuhan ke- dan an, maka kata kebijakan berarti "rangkaian konsep dan asas yang menjadi garis besar dan dasar rencana dalam pelaksanaan suatu pekerjaan, kepemimpinan" (Departemen Pendidikan Nasional, 2002: 149).

Pengertian di atas setidaknya memberikan dua poin penting yang perlu dipahami, yaitu: pertama, pengambilan keputusan mesti didasarkan kepada pertimbangan-pertimbangan logis sehingga dapat diterima oleh semua pihak yang menjadi sasaran keputusan tersebut. Kedua, pengambilan keputusan yang pada gilirannya melahirkan satu atau lebih keputusan dapat dijadikan sebagai garis-garis besar untuk melakukan suatu pekerjaan, profesi atau kepemimpinan.

Bertitik tolak dari pengertian di atas, maka pengertian kebijakan dalam pendidikan merupakan keseluruhan proses dan hasil perumusan langkah-langkah strategis pendidikan, yang dijabarkan dari visi, misi pendidikan, dalam rangka untuk mewujudkan tercapainya tujuan pendidikan dalam suatu masyarakat untuk suatu kurun waktu tertentu (Tilaar, 2008: 140). Begitu pula halnya kebijakan dalam pendidikan Islam, harus pula relevan dengan visi, misi pendidikan Islam. Menurut Tilaar (2008: 149), visi pendidikan Islam untuk wilayah Indonesia adalah mewujudkan manusia Indonesia yang takwa dan produktif sebagai anggota masyarakat Indonesia yang ber-Bhinneka. Sementara misi pendidikan Islam adalah mewujudkan nilai-nilai keislaman di dalam pembentukan manusia Indonesia, yaitu manusia yang saleh dan produktif.
Pengertian Pengambilan Keputusan

Keputusan adalah pengakhiran daripada proses pemikiran tentang apa yang dianggap sebagai "masalah" sebagai sesuatu yang merupakan penyimpangan daripada yang dikehendaki, direncanakan atau dituju dengan menjatuhkan pilihan pada salah satu alternatif pemecahannya (Atmosudirdjo, 1990: 45). Menurut Siagian (dalam Asnawir, 2006: 203), pengambilan keputusan merupakan suatu pendekatan yang sistematis terhadap suatu masalah yang dihadapi. Dikatakan lebih lanjut bahwa masalah tersebut menyangkut pengetahuan tentang hakikat dari masalah yang dihadapi, analisis masalah dengan mempergunakan fakta dan data, mencari alternatif yang paling rasional dan penilaian hasil yang dicapai sehingga akibat dari keputusan yang diambil akan dapat menjawab pertanyaan tentang apa yang harus diperbuat untuk mengatasi masalah tersebut dengan menjatuhkan pilihan (choice) pada salah satu alternatif tertentu.

Dapat diartikan bahwa pengambilan keputusan adalah memilih dan menetapkan satu alternatif yang dianggap paling tepat dari beberapa alternatif yang dirumuskan. Keputusan itu harus bersifat fleksibel, analitis dan mungkin untuk dilaksanakan dengan dorongan sarana prasarana dan sumber daya yang tersedia (berupa manusia dan material).

Dasar pengambilan keputusan itu bermacam-macam, tergantung dari permasalahannya. Keputusan dapat diambil berdasarkan perasaan semata-mata, dapat pula keputusan dibuat berdasarkan rasio. Selain tergantung kepada permasalahannya, pengambilan keputusan juga tergantung kepada individu yang membuat keputusan. Atas dasar hal ini, Terry (dalam Syamsi, 2000: 16-17) mengemukakan beberapa dasar pengambilan keputusan, yaitu: (1) pengambilan keputusan berdasarkan intuisi, (2) pengambilan keputusan berdasarkan rasional, (3) pengambilan keputusan berdasar-kan fakta, (4) pengambilan keputusan berdasar-kan pengalaman dan (5) pengambilan keputusan berdasarkan wewenang.

Sementara dalam konteks pendidikan Islam, hal terpenting yang harus diperhatikan dalam rangka pengambilan keputusan adalah 
bagaimana keputusan itu ditetapkan atas dasar musyawarah mufakat. Sebab, dalam praktik kehidupan umat Islam setiap permasalahan yang dihadapi senantiasa menempuh cara musyawarah dalam setiap pengambilan keputusan. Musyawarah sangat diperlukan sebagai bahan pertimbangan dan tanggungjawab bersama pada setiap proses pengambilan keputusan, sehingga setiap keputusan yang dikeluarkan akan menjadi tanggung jawab bersama.

Sikap musyawarah merupakan sebentuk penghargaan terhadap orang lain, karena pendapat-pendapat yang disampaikan menjadi pertimbangan bersama. Allah SWT berfirman: "Maka disebabkan rahmat dari Allah-lah kamu berlaku lemah lembut terhadap mereka. Sekiranya kamu bersikap keras lagi berhati kasar, tentulah mereka menjauhkan diri dari sekelilingmu. karena itu ma'afkanlah mereka, mohonkanlah ampun bagi mereka, dan bermusyawaratlah dengan mereka dalam urusan itu. kemudian apabila kamu telah membulatkan tekad, maka bertawakkallah kepada Allah. Sesungguhnya Allah menyukai orang-orang yang bertawakkal kepada-Nya" (QS. Ali Imran: 159). Pada ayat lain Allah SWT juga berfirman: "Dan (bagi) orang-orang yang menerima (mematuhi) seruan Tuhannya dan mendirikan shalat, sedang urusan mereka (diputuskan) dengan musyawarat antara mereka; dan mereka menafkahkan sebagian dari rezki yang Kami berikan kepada mereka" (QS. al-Syura ayat 38).

Musyawarah pun seharusnya menjadi jalan yang ditempuh oleh dunia pendidikan dalam setiap pengambilan keputusan dengan melibatkan semua komponen yang terlibat di dunia pendidikan seperti pendidik, peserta didik, orang tua dan masyarakat sehingga setiap keputusan yang diambil dapat diterima dan dijalankan dengan baik oleh semua komponen tersebut, karena dalam musyawarah terdapat nilai-nilai kebajikan yang sangat tepat jika diterapkan di dunia pendidikan.

\section{JENIS-JENIS PENGAMBILAN KEPUTU- SAN}

Jenis-jenis pengambilan keputusan dilihat dari personal yang melakukan-nya dapat dibagi kepada dua, yaitu: keputusan individual dan keputusan kelompok. Keputusan individual merupakan pengambilan keputusan yang dilakukan oleh pemimpin atau manajer secara sendiri; sedangkan keputusan kelompok adalah keputusan yang dibuat oleh sekelompok orang berdasarkan hasil musyawarah mufakat.

Pengambilan keputusan secara kelompok dapat pula dibedakan kepada beberapa bentuk yaitu: (1) sekelompok pimpinan, (2) sekelompok orang-orang bersama pimpinannya dan (3) sekelompok orang yang mempunyai kedudukan sama dan keputusan kelompok. Beberapa kebaikan dari pengambilan keputusan secara kelompok adalah: (1) keputusan dapat lebih cepat ditentukan atau diambil karena tidak perlu menunggu persetujuan dari rekan lainnya, (2) memperkecil kemungkinan terjadinya pertentangan pendapat dan (3) jika pimpinan atau manajer yang mengambil keputusan itu memiliki kemampuan yang tinggi dan berpengalaman luas dalam bidang yang akan diputuskan, maka keputusannya berkemungkinan besar tepat.

Di samping beberapa kebaikan di atas, terdapat pula beberapa kelemahan pengambilan keputusan secara kelompok, yaitu: (1) bagaimanapun tingginya kepandaian dan kemampuan pimpinan atau manajer, tetap memiliki berbagai keterbatasan, (2) keputusan yang terlalu cepat diambil dan tidak meminta pendapat orang lain seringkali kurang tepat dan (3) jika terjadi kesalahan dalam pengambilan keputusan dapat menjadi beban yang berat bagi pimpinan itu sendiri.

Tampak jelas bahwa secara garis besar jenis-jenis pengambilan keputusan itu ada dua, yaitu keputusan secara individu dan keputusan secara kelompok. Kedua jenis pengambilan keputusan tersebut tentu saja memiliki kebaikan dan kelemahan masing-masing. Kendati demikian kelemahan-kelemahan tersebut akan dapat diatasi jika pemimpin atau manajer dapat mengetahui dan memahami dengan baik 
prinsip-prinsip dalam pengambilan suatu keputusan.

\section{TAHAP-TAHAP PENGAMBILAN KEPU- TUSAN}

Pengambilan keputusan tidak dapat dilakukan seperti membalik telapak tangan. Hal tersebut dikarenakan keputusan tersebut pada gilirannya akan memberi dampak terhadap banyak aspek. Oleh sebab itu, untuk mendapatkan keputusan yang akurat dan penuh pertimbangan harus melalui tahapan-tahapan tertentu sehingga kemungkinan timbulnya dampak negatif dari keputusan tersebut dapat diminimalisir.

Menurut Herbart A. Simon (dalam Asnawir, 2006: 215), setidaknya ada tiga tahap yang ditempuh dalam pengambilan keputusan, yaitu: (1) Tahap penyelidikan; tahap ini dilakukan dengan mempelajari lingkungan atas kondisi yang memerlukan keputusan. Pada tahap ini data mentah yang diperoleh, diolah dan diuji serta dijadikan petunjuk untuk mengetahui atau mengenal persoalan. (2) Tahap perancangan; pada tahap ini dilakukan pendaftaran, pengembangan, penganalisaan arah tindakan yang mungkin dilakukan dan (3) Tahap pemilihan; pada tahap ini dilakukan kegiatan pemilihan arah tindakan dari semua yang ada.

Ketiga tahapan pengambilan keputusan yang ditawarkan oleh Herbart di atas dapat diilustrasikan seperti pada gambar berikut:

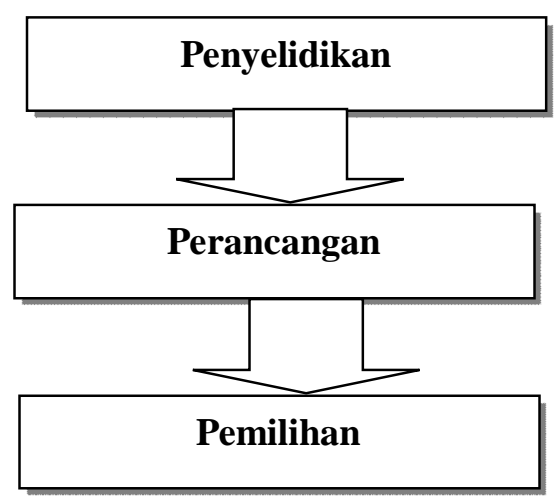

\section{GAYA DAN MODEL PENGAMBILAN KEPUTUSAN}

Gaya dan model pengambilan keputusan erat kaitannya dengan beberapa tahap yang ditempuh dalam pengambilan keputusan. Artinya, model-model pengambilan keputusan yang dilakukan oleh seorang pimpinan atau manajer dapat dilihat dari ketiga tahapan pengambilan keputusan yang telah dipaparkan sebelumnya, yaitu: tahap penyelidikan, tahap perancangan dan tahap penilaian. Kendati demikian, hal penting yang perlu dibahas berkenaan dengan model atau gaya pengambilan keputusan ini adalah bahwa seorang pimpinan atau manajer perlu memenuhi beberapa persyaratan yaitu: (1) mengetahui semua perangkat alternatif dan semua akibat atau hasil yang akan diperoleh, (2) mengetahui metode dalam membuat urutan kepentingan dan semua alternatif dan (3) memilih alternatif yang paling menguntungkan untuk dilaksanakan.

Dapat pula dikemukakan bahwa model atau gaya pengambilan keputusan ini berkaitan erat dengan tipe kepemimpinan seseorang. Seseorang yang memiliki tipe kepemimpinan otoriter tentu dalam pengambilan keputusan juga akan bersikap otoriter, sehingga kurang menerima atau mempertimbangkan pendapat atau usulan yang datang dari orang lain.

Anwar (2003: 68-69) mengidentifikasi setidaknya terdapat tiga tipe dalam kepemimpinan, yaitu: (1) tipe normatif, mengasumsikan bahwa tujuan-tujuan yang digariskan akan mempercepat pencapaian tujuan lembaga dalam kepemimpinannya. Jalan yang sangat memungkinkan untuk mencapai tujuan lebih ditentukan pada struktur organisasi daripada menggunakan orang tertentu. Bila dikaitkan dengan administrasi, maka administrasi yang baik ditandai oleh efektivitas organisasi yang lebih menonjol daripada efisiensi waktu. (2) tipe personal, asumsinya bahwa jalan terbaik untuk mewujudkan tujuantujuan adalah lebih kepada keterlibatan individu daripada hanya mempercayakan kepada struktur organisasi. Artinya, penentu baik buruknya administrasi bukanlah efektivitas organisasi, akan tetapi efisiensi individunya. (3) tipe 
transaksional, merupakan gaya sementara untuk mencapai gaya lain yang sangat bergantung kepada situasi. Gaya ini lebih menekankan kebutuhan untuk bergeser sambil berubah ke arah yang lebih baik tanpa mengubah urutan organisasi maupun pribadi yang terlibat di dalamnya. Ukuran baik buruknya administrasi dalam tipe kepemimpinan ini ditentukan oleh efektivitas organisasi dan efektivitas individu.

Menurut Syamsi (2000: 98-99) khusus pengambilan keputusan dalam kelompok, ada dua teknik yang dapat dilakukan, yaitu: pertama, teknik Delphi. Pada teknik ini setelah pucuk pimpinan memberitahukan adanya masalah yang perlu dipecahkan bersama, para pimpinan diminta pendapat atau ide mereka, saran-saran dan pandangan secara tertulis mengenai rencana keputusan yang akan diambilnya. Pendapat dan saran mereka disampaikan tanpa menyebutkan identitas penyarannya dalam rangka solidaritas. Setelah dikumpulkan mereka diminta untuk saling menanggapi terhadap masukan-masukan yang ada. Masukan-masukan tersebut menunjukkan adanya kontribusi kecakapan, keterampilan, kemauan dan juga kontribusi informasi. Akhirnya keputusan yang baik dapat diambilnya. Teknik Delphi ini dimaksudkan untuk menghindari hubungan langsung yang kurang enak, karena menonjolnya ide yang lebih bagus dari salah seorang dibandingkan dengan ide yang lain. Dengan teknik Delphi ini dapatlah dihindarkan perasaan tersinggung bagi yang idenya kalah baik. Tetapi keburukannya antara lain hanya karena untuk menghindarkan rasa tidak enak saja, maka tidak diberikan kesempatan berkomunikasi secara langsung. Padahal ada baiknya kalau ada pendapat yang lebih baik itu dianggap sebagai penambahan pengetahuan bagi yang lainnya.

Kedua, teknik kelompok nominal. Pertemuan kelompok ini merupakan pertemuan kelompok struktural yang tugasnya memberikan tanggapan dan saran secara tertulis. Setelah itu, masing-masing orang diminta menulis ide pokok atau pendapatnya di white board secara bergantian. Kemudian pendapat-pendapat yang telah tertulis itu dibicarakan bersama secara terbuka. Setiap ide dibicarakan sampai tuntas.
Akhirnya jika tidak ada kata sepakat bulat, maka perlu voting.

Perbedaan kedua teknik pengambilan keputusan di atas pada pokoknya adalah bahwa teknik Delphi merupakan teknik pengambilan keputusan kelompok secara lebih tertutup; sedangkan teknik kelompok nominal lebih bersifat terbuka. Kendati demikian, teknik mana yang akan digunakan oleh seorang pimpinan atau manajer sangat tergantung kepada situasi yang berlangsung pada saat akan melakukan pengambilan keputusan.

\section{BEBERAPA HAL YANG MEMPENGA- RUHI PENGAMBILAN KEPUTUSAN}

Pengambilan keputusan yang dilakukan oleh seorang pemimpin atau manajer dapat dipengaruhi oleh beberapa faktor berikut:

Pertama, dinamika individu. Antara individu dengan organisasi saling mempengaruhi. Begitu juga antara individu yang satu dengan individu yang lain juga mengalami perbedaan dalam mengambil keputusan untuk kepentingan pribadinya. Seseorang dalam pengambilan keputusan untuk organisasi selalu dipengaruhi oleh kepentingan pribadinya.

Kedua, dinamika kelompok. Dinamika kelompok sangat dipengaruhi oleh jumlah individu sebagai anggota kelompok yang bersangkutan. Norma yang dimiliki oleh kelompok tersebut sangat besar pengaruhnya terhadap cara berpikir, menanggapi suatu gejala sosial dan tingkah laku seseorang. Perubahan sikap (attitude), pendapat (opiny) dan tingkah laku (behavior) dalam menanggapi rangsanganrangsangan sosial akan disesuaikan dengan norma kelompok. Pengaruh norma kelompok itu penting diperhatikan oleh para manajer karena karena para bawahannya terdiri dari individuindividu yang tergabung dalam organisasi yang ia pimpin.

Ketiga, dinamika lingkungan. Lingkungan ialah situasi, kondisi dan faktor-faktor yang berkaitan dengan suatu keputusan. Keputusan yang diambil merupakan jawaban terhadap suatu tantangan atau suatu masalah yang dihadapi yang timbul sebagai akibat 
perubahan, situasi dan kondisi. Perubahan situasi dan kondisi tersebut sangat ditentukan oleh derajat keputusan yang diambil. Derajat keputusan sangat ditentukan pula oleh jenis dan luasnya lingkup organisasi.

Bagaimanapun kecilnya derajat keputusan tetap menimbulkan pengaruh pada lingkungan. Seorang manajer perlu memperhatikan dinamika lingkungan. Hal tersebut akan memperluas wawasannya dalam mengambil keputusan. Suatu keputusan yang diambil tersebut tidak berdiri sendiri, tetapi saling terkait satu sama lain, dan akan menimbulkan perubahan dalam lingkungan keputusan tersebut. Perubahan dimaksud dapat menim-bulkan masalah yang memerlukan pemecahan. Pemecahan satu masalah akan menimbulkan masalah baru yang untuk pemecahannya diperlukan pengambilan keputusan pula.

Selain beberapa faktor di atas, terdapat beberapa faktor lain yang juga mempengaruhi seseorang dalam pengambilan keputusan, yaitu: (1) sistem nilai yang berlaku dalam hubungan antara individu dan masyarakat, (2) persepsi atau pandangan seseorang terhadap suatu masalah. Persepsi ini juga dipengaruhi oleh sistem nilai yang berlaku dan pengalaman yang dimiliki/dialami, (3) keterbatasan manusiawi antara lain ketidakmampuan mengumpulkan informasi secara langsung, (4) perilaku politik, kekuasaan dan kekuatan yang terjadi. Banyak keputusan yang diambil tidak maksimal, tetapi hanya merumuskan perilaku politik tertentu, (5) keterbatasan waktu, kesibukan waktu, mengakibatkan informasi-informasi yang diperoleh sangat terbatas pula untuk digunakan dalam pengambilan keputusan dan (6) gaya kepemimpinan yang dimiliki seseorang juga akan mewarnai corak keputusan yang diambil (Asnawir, 2006: 221-222).

\section{SIMPULAN}

Dasar utama kebijakan dan pengambilan keputusan dalam pendidikan Islam adalah visi dan misi pendidikan Islam itu sendiri. Oleh sebab itu, apapun bentuk kebijakan dan keputusan yang diambil senantiasa mengacu kepada visi dan misi tersebut tanpa mengabaikan nilai-nilai yang terkandung di dalamnya. Secara teknis, pengambilan keputusan dalam pendidikan Islam mesti didasarkan kepada musyawarah untuk mencapai mufakat sehingga hasil dari keputusan secara bersama itu dapat pula dipertanggungjawabkan secama bersama.

\section{DAFTAR RUJUKAN}

Anwar, Moch. Idochi. 2003. Administrasi Pendidikan dan Manajemen Biaya Pendidikan, Bandung, Alfabeta

Asnawir, Manajemen Pendidikan, 2006. Padang, IAIN IB Press

Atmosudirdjo, Prajudi, 1990. Beberapa Pandangan Umum Tentang

Pengambilan Keputusan (Decision making), Jakarta, Ghalia Indonesia

Departemen Agama RI, 1995. al-Quran dan Terjemahnya, Semarang, Toha Putra

Departemen Pendidikan Nasional, 2002. Kamus Besar Bahasa Indonesia, Jakarta, Balai Pustaka

Fatah, Nanang, 2006. Landasan Manajemen Pendidikan, Bandung: Remaja Rosdakarya

Kartono, Kartini, 1988. Pimpinan dan kepemimpinan. Jakarta: Ghalia Indonesia

Langgulung, Hasan, 2003. Asas-Asas Pendidikan Islam, Jakarta: Pustaka Al Husna Baru

Marno dkk., 2008. Manajemen dan Kepemimpinan Pendidikan Islam, Bandung, Refika Aditama

Mujamil Qomar, 2010. Manajemen Pendidikan Islam, Malang, Erlangga

Nawawi, Hadari, 1993. Kepemimpinan Menurut Islam, Yogyakarta, Gajah Mada University Press

Sagala, Syaiful, 2000. Administrasi Pendidikan Kontemporer, Bandung: Alfabeta 
Siswanto, H.B., 2006. Pengantar Manajemen, Jakarta: Bumi Aksara

Syamsi, Ibnu, 2000. Pengambilan Keputusan dan Sistem Informasi, Jakarta: Bumi Aksara judul asli: Guide to Management, Jakarta: Bumi Aksara

Tilaar, H.A.R., 2008. Manajemen Pendidikan Nasional, Bandung, Remaja Rosdakarya

Terry, G.R., 2006. Prinsip-Prinsip Manajemen, diterjemahkan oleh J. Smith D.F.M, dari 